\title{
Pengaruh Penerapan Metode Drill Terhadap Hasil Belajar Mata Pelajaran Pendidikan Agama Islam
}

\author{
Agus Hendro Priyono ${ }^{1 *}$ dan M. Fathoni ${ }^{2 *}$ \\ ${ }^{1}$ STKIP Nurul Huda \\ ${ }^{2}$ Dosen STKIP Nurul Huda \\ E-mail: agushendropriyono@gmail.com \\ *E-mail: mfathoni@stkipnurulhuda.ac.id
}

\begin{abstract}
Abstrak
Ketercapaian tujuan Pendidikan Agama Islam merupakan tujuan akhir kegiatan pembelajaran. Keberhasilan belajar dipengaruhi oleh berbagai macam faktor, salah satunya adalah metode pembelajaran. Penelitian ini dilatarbelakangi hasil observasi pendahuluan yang menunjukkan bahwa pembelajaran Pendidikan Agama Islam di SMP Negeri 1 Buay Pemuka Peliung kurang maksimal karena sistem pembelajaran berpusat pada guru sehingga peserta didik tidak dapat terlibat aktif mengikuti kegiatan pembelajaran dan berimplikasi pada pencapaian hasil belajar yang kurang maksimal. Penelitian ini menawarkan metode Drill. Tujuan penelitian ini adalah untuk mengetahui pengaruh penerapan metode Drill terhadap hasil belajar mata pelajaran Pendidikan Agama Islam peserta didik kelas VIII SMP Negeri 1 Buay Pemuka Peliung. Simpulan penelitian yaitu Pertama: Hasil belajar mata pelajaran Pendidikan Agama Islam peserta didik kelas VIII SMP Negeri 1 Buay Pemuka Peliung yang pembelajarannya menerapkan metode Drill memperoleh nilai kategori tinggi dengan nilai ratarata kelas sebesar 78,40. Kedua: Hasil belajar mata pelajaran Pendidikan Agama Islam peserta didik kelas VIII SMP Negeri 1 Buay Pemuka Peliung yang pembelajarannya menerapkan metode ceramah memperoleh nilai kategori rendah dengan nilai rata-rata kelas sebesar 67,69. Ketiga: Berdasarkan hasil uji hipotesis, terdapat pengaruh penerapan metode Drill terhadap hasil belajar mata pelajaran Pendidikan Agama Islam peserta didik kelas VIII SMP Negeri 1 Buay Pemuka Peliung.
\end{abstract}

Kata kunci: Metode Drill, Hasil Belajar, Pendidikan Agama Islam.

\section{PENDAHULUAN}

Salah satu bentuk pendidikan di lembaga-lembaga pendidikan formal Indonesia adalah Pendidikan Agama Islam. Hawi (2008:9) mengemukakan, "Pendidikan Agama Islam adalah suatu sistem pendidikan yang bertujuan untuk membentuk individu menjadi bercorak diri yang bernilai tertinggi menurut ukuran Allah dengan mempergunakan isi ajaran Allah menjadi bahan pembentukannya". Ketercapaian tujuan Pendidikan Agama Islam sebagaimana tersebut merupakan tujuan akhir kegiatan pembelajaran yang disebut dengan hasil belajar Pendidikan Agama Islam. Keberhasilan belajar Pendidikan Agama Islam dipengaruhi oleh berbagai macam faktor yang salah satunya adalah faktor metode pembelajaran. Metode pembelajaran sebagai salah satu faktor yang mempengaruhi proses pembelajaran harus benar-benar sesuai dengan karakteristik dari materi pembelajaran, peserta didik maupun kurikulum yang diberlakukan. Kekurangtepatan metode pembelajaran yang digunakan pada kegiatan pembelajaran akan mengakibatkan pembelajaran tidak dapat berjalan secara maksimal. Hal tersebut sebagaimana terjadi di SMP Negeri 1 Buay Pemuka Peliung.

Berdasarkan hasil penelitian pendahuluan dengan melakukan observasi pada pembelajaran Pendidikan Agama Islam di SMP Negeri 1 Buay Pemuka Peliung. Hasil observasi kegiatan pembelajaran Pendidikan Agama Islam di SMP Negeri 1 Buay Pemuka Peliung yang telah dilakukan selama dua bulan melalui kegiatan praktek pengalaman lapangan menunjukkan bahwa terdapat kelemahan sistem pembelajaran Pendidikan Agama Islam di SMP Negeri 1 Buay Pemuka Peliung baik dari faktor pendidik maupun dari faktor peserta didik. Dari faktor pendidik kelemahan yang terjadi dalam pembelajaran Pendidikan Agama Islam di SMP Negeri 1 Buay Pemuka Peliung adalah 
pelaksanaan pembelajaran oleh pendidik dilakukan menggunakan metode pembelajaran yang berpusat pada pendidik yaitu metode pembelajaran ceramah. Penerapan metode ceramah oleh pendidik dilaksanakan tanpa variasi dengan metode pembelajaran lain. Pembelajaran demikian menjadikan pendidik sebagai sentral pembelajaran yang aktif, sedangkan peserta didik hanya menjadi pendengar pasif.

Kelemahan pembelajaran Pendidikan Agama Islam di SMP Negeri 1 Buay Pemuka Peliung juga terjadi pada faktor peserta didik. Hasil observasi menunjukkan bahwa selama kegiatan pembelajaran peserta didik bersikap pasif. Ketika pendidik memberikan kesempatan kepada peserta didik untuk mengajukan pertanyaan, hanya beberapa orang peserta didik yang dapat mengajukan pertanyaan. Selain itu, ketika pendidik menjelaskan materi pembelajaran, tampak terjadi kejenuhan dan kebosanan pada diri peserta didik. Sebagian kecil peserta didik yang memperhatikan penjelasan pendidik, sedangkan peserta didik lain terlihat cuek atau bersikap apatis. Sikap apatis peserta didik ditunjukkan sikap peserta didik yang terlihat berbicara dengan teman sebangku, ribut di dalam kelas seperti saling melempar kertas dengan peserta didik lain, terdapat juga peserta didik melakukan kegiatan lain seperti menggambar tidak jelas pada buku pelajaran, bahkan terdapat peserta didik keluar kelas dengan berbagai alasan.

Keadaan peserta didik pada pembelajaran Pendidikan Agama Islam di SMP Negeri 1 Buay Pemuka Peliung menjadikan pemahaman peserta didik terhadap materi pembelajaran hanya bersifat verbalis teoritis dalam arti peserta didik mengetahui materi pembelajaran namun tidak dapat mengaplikasikan materi pembelajaran dalam menyelesaikan permasalahan. Selain itu, berdasarkan hasil nilai murni midle semester genap diketahui bahwa hasil belajar mata pelajaran Pendidikan Agama Islam peserta didik masih tergolong rendah yaitu dari 106 siswa hanya terdapat 49 peserta didik atau 46,22\% dapat mencapai ketuntasan dengan memperoleh nilai $\geq 70$, sedangkan 57 peserta didik atau $53,77 \%$ belum mencapai ketuntasan atau memperoleh nilai $<70$. Nilai rata-rata peserta didik pada pembelajaran Pendidikan Agama Islam adalah 53,36.

Berdasarkan permasalahan pada pembelajaran Pendidikan Agama Islam di SMP Negeri 1 Buay Pemuka Peliung, peneliti menawarkan metode pembelajaran baru untuk diterapkan yaitu metode Drill. Metode Drill merupakan satu kegiatan melakukan hal yang sama, berulang-ulang secara sungguh-sungguh dengan tujuan untuk menyempurnakan suatu keterampilan agar menjadi permanen. Hal tersebut sebagaimana penjelasan Roestiyah (2008:112) yang menyatakan "Metode Drill adalah suatu cara mengajar peserta didik melakukan kegiatan latihan, peserta didik memiliki ketangkasan dan keterampilan lebih tinggi dari apa yang dipelajari”.

Dasar filosofi metode Drill adalah filsafat pendidikan behaviorisme yang dipelopori Thorndike. Konsep dasar filosofi metode Drill sesuai filsafat behaviorisme menurut Budiningsih (2011:13) adalah "learning to do atau belajar dengan melakukan sehingga belajar akan dapat berhasil apabila peserta didik dapat melakukan suatu kegiatan sesuai materi pembelajaran". Konsep tersebut kemudian dijadikan dasar pada metode Drill dimana peserta didik dalam mengikuti pembelajaran Pendidikan Agama Islam harus berlatih untuk melakukan suatu kegiatan sesuai materi pembelajaran sehingga konsep learning to do benar-benar dapat diimplementasikan dan peserta didik memiliki kecakapan mempraktekkan materi pembelajaran.

Penerapan metode Drill diharapkan dapat menjadikan suasana pembelajaran lebih komunikatif dimana peserta didik dituntut untuk selalu berperan aktif mengikuti seluruh kegiatan pembelajaran. Peserta didik pada pembelajaran menggunakan metode Drill bukan hanya dilatih untuk memahami materi pembelajaran, namun juga dilatih untuk dapat mengimplementasikan materi pembelajaran sehingga menjadi satu kebiasaan pada diri peserta didik. Dengan demikian pemahaman peserta didik tidak terbatas pada pengetahuan terhadap konsep namun juga implementasi konsep yang dapat menunjang ketercapaian hasil belajar peserta didik secara lebih maksimal.

Berdasarkan penjelasan metode Drill, maka metode Drill dipilih untuk diterapkan pada mata pelajaran Pendidikan Agama Islam di kelas VIII SMP Negeri 1 Buay Pemuka Peliung. Pemilihan metode Drill didasarkan pada asumsi bahwa materi pembelajaran Pendidikan Agama Islam bersifat 
teoretis praktis sehingga selain peserta didik mengetahui berbagai materi pembelajaran, peserta didik juga dituntut untuk dapat mengimplementasikan materi pembelajaran secara praktis. Karakteristik materi pembelajaran Pendidikan Agama Islam sebagaimana tersebut menuntut pelaksanaan pembelajaran secara teoretis praktis yang salah satunya adalah dengan menerapkan metode Drill. Melalui penerapan metode Drill diharapkan peserta didik memiliki kemampuan motoris atau gerak seperti menghafalkan kata-kata, menulis, mempergunakan alat, mengembangkan kecakapan intelektual seperti menganalisis suatu masalah serta memiliki kemampuan menghubungkan antara suatu keadaan dengan keadaan lain dalam memecahkan suatu masalah yang pada akhirnya akan meningkatkan pemahaman peserta didik terhadap materi pembelajaran.

\section{Metode Drill}

Salah satu bentuk metode pembelajaran yang sering digunakan pada kegiatan pembelajaran berbasis aktivitas belajar peserta didik adalah metode Drill. Roestiyah (2008:112) memberikan penjelasan tentang metode Drill sebagai berikut:

Metode Drill berasal dari metode pengajaran Herbart yaitu metode assosiasi dan ulangan tanggapan untuk memperkuat tanggapan pelajaran pada peserta didik. Pelaksanaan secara mekanis untuk mengajarkan berbagai mata pelajaran dan kecakapan, sehingga menimbulkan verbalisme pengetahuan peserta didik, kebiasaan menghafal secara mekanis tanpa pengertian.

Pengertian tersebut menunjukkan bahwa metode Drill merupakan metode pembelajaran yang dilaksanakan dengan cara mengulang-ulang materi pembelajaran yang disampaikan melalui kegiatan pelatihan. Berkaitan pengertian metode Drill Suparno (2008:73) menjelaskan sebagai berikut:

Secara gramatikal kata Drill berarti berlatih mengeja kata, menghapal, dan lain sebagainya, sehingga dapat disimpulkan bahwa Drill adalah latihan dengan praktek yang dilakukan berulang kali atau kontinyu untuk mendapatkan keterampilan dan ketangkasan praktis tentang pengetahuan yang dipelajari. Lebih dari itu diharapkan agar pengetahuan atau keterampilan yang telah dipelajari itu menjadi permanen, mantap dan dapat dipergunakan setiap saat oleh yang bersangkutan.

Penjelasan tersebut menunjukkan bahwa metode Drill merupakan metode pembelajaran yang menekankan pada pelatihan terhadap berbagai kecakapan tertentu pada diri peserta didik. Pendapat tersebut didukung Djamarah (2010:95) yang menjelaskan sebagai berikut:

Metode Drill disebut juga metode latihan yang disebut juga dengan training merupakan suatu cara melaksanakan pembelajaran yang baik untuk menanamkan kebiasaankebiasaan tertentu. Juga sebagai sarana untuk memelihara kebiasaan-kebiasaan yang baik. Selain itu metode Drill merupakan metode pembelajaran yang digunakan agar peserta didik dapat memperoleh suatu ketangkasan, ketepatan, kesempatan dan keterampilan.

Pengertian metode Drill sebagaimana tersebut memberikan kejelasan bahwa metode Drill merupakan metode pembelajaran yang dilaksanakan dengan memberikan berbagai latihan atau training kepada peserta didik untuk memperoleh berbagai kecakapan tertentu. Pengertian tersebut diperjelan Sudjana (2012:86) yang menyatakan, "Metode Drill adalah metode dalam pembelajaran dengan melatih peserta didik terhadap bahan yang sudah diajarkan atau berikan agar memiliki ketangkasan atau ketrampilan dari apa yang telah dipelajari".

Metode Drill dilaksanakan dengan menekankan latihan kecakapan peserta didik secara berulang-ulang. Latihan dapat dilaksanakan perseorangan, kelompok, ataupun klasikal. Menentukan apakah latihan yang dilakukan bersifat perseorangan, kelompok, atau klasikal didasarkan atas memadai atau tidak sarana dan prasarana. Selain itu, penentuan bentuk pelatihan juga didasarkan atas berbagai pertimbangan pendidik. Berkaitan langkah-langkah pelaksanaan metode Drill, Sumiati (2008:105) mendeskripsikan sebagai berikut: 
a. Pendidik memberi penjelasan singkat tentang konsep, prinsip, atau aturan yang menjadi dasar dalam melaksanakan pekerjaan yang akan dilatihkan.

b. Pendidik mempertunjukkan bagaimana melakukan pekerjaan itu dengan baik dan benar sesuai dengan konsep dan aturan tertentu. Pada bentuk pelajar verbal yang dipertun jukkan adalah pengucapan atau penulisan kata atau kalimat.

c. Jika belajar dilakukan secara kelompok atau klasikal, pendidik dapat memerintah salah seorang peserta didik untuk menirukan apa yang telah dilakukan pendidik, sementara s iswa lain memperhatikan.

d. Latihan perseorangan dapat dilakukan melalui bimbingan dari pendidik sehingga dicapai hasil belajar sesuai dengan tujuan.

Berdasarkan penjelasan metode Drill disimpulkan bahwa metode Drill adalah latihan dengan praktek yang dilakukan berulang kali secara kontinyu untuk mendapatkan keterampilan dan ketangkasan praktis tentang pengetahuan yang dipelajari. Metode Drill merupakan metode pembelajaran yang dilaksanakan dengan memberikan berbagai bentuk pelatihan sesuai materi pembelajaran agar menjadi suatu kebiasaan dan kecakapan yang dimiliki peserta didik.

\section{Hasil Belajar Pendidikan Agama Islam}

Istilah hasil belajar pada kegiatan pembelajaran sering diartikan atau disamakan dengan prestasi belajar. Sanjaya (2010:214) menjelaskan pengertian hasil belajar sebagai berikut:

Hasil belajar adalah sesuatu yang diperoleh peserta didik sebagai konsekuaensi dari upaya yang telah dilakukan sehingga terjadi perubahan perilaku pada yang bersangkutan baik perilaku dalam bidang kognitif, afektif maupun psikomotorik. Umumnya hasil belajar itu ditunjukkan melalui nilai atau angka yang diperoleh peserta didik setelah dilakukan serangkaian proses evaluasi hasil belajar. Besar kecilnya imbalan yang diberikan akan memengaruhi kepuasan belajar, dan setiap kepuasan yang ditimbulkan dari imbalan akan berpengaruh kepada besar kecilnya motivasi.

Sudjana (2008:15) berpendapat bahwa, "Hasil belajar adalah kemampuan-kemampuan yang dimiliki peserta didik setelah menerima pengalaman belajarnya". Sementara Tu'u (2007:75) mengatakan, "Hasil belajar adalah hasil yang dicapai seseorang ketika mengerjakan tugas atau kegiatan belajar tertentu". Kedua definisi tersebut menunjukkan bahwa hasil belajar merupakan tujuan akhir dilaksanakan kegiatan pembelajaran di sekolah. Hasil belajar dapat ditingkatkan melalui usaha sadar yang dilakukan secara sistematis mengarah kepada perubahan yang positif yang kemudian disebut dengan proses belajar. Akhir dari proses belajar adalah perolehan suatu hasil belajar peserta didik.

Berdasarkan penjelasan tentang pengertian hasil belajar dapat disimpulkan bahwa hasil belajar adalah prestasi belajar yang dicapai siswa dalam proses kegiatan pembelajaran dengan membawa suatu perubahan dan pembentukan tingkah laku seseorang. Hasil belajar Pendidikan Agama Islam merupakan tingkat pemahaman yang diperoleh siswa setelah mengikuti kegiatan pembelajaran Pendidikan Agama Islam atau tingkat ketercapaian kompetensi yang diperoleh siswa setelah kegiatan pembelajaran berakhir.

\section{METODE/EKSPERIMEN}

Berdasarkan jenis data serta teknik analisis data yang digunakan, penelitian ini termasuk penelitian kuantitatif. Menurut Sugiyono (2013:7), "Metode penelitian kuantitatif dapat diartikan sebagai metode penelitian yang berlandaskan pada filsafat positivisme, digunakan untuk meneliti pada populasi atau sampel tertentu". Metode kuantitatif disebut sebagai metode positivistik karena berlandaskan pada filsafat positivisme. Penelitian ini jika dilihat tingkat eksplanasi termasuk jenis penelitian eksperimen. Dantes (2012:85) menjelaskan bahwa "Penelitian eksperimen merupakan penelitian yang dimaksudkan untuk mengetahui ada tidaknya akibat dari sesuatu yang dikenakan pada subjek selidiki". Sesuai metode penelitian yang digunakan, maka jenis penelitian yang digunakan adalah quasi eksperiment. 
Penelitian ini memiliki satu variabel bebas yaitu penerapan metode Drill. Penelitian juga memiliki satu variabel terikat yaitu hasil belajar peserta didik pada mata pelajaran Pendidikan Agama Islam. Penelitian ini berupaya mengetahui ada tidaknya pengaruh variabel dependen terhadap variabel independen. Populasi dalam penelitian ini adalah seluruh peserta didik kelas VIII SMP Negeri 1 Buay Pemuka Peliung Kabupaten OKU Timur yang berjumlah 121 orang. Sampel penelitian ini adalah peserta didik kelas VIII-1 dan kelas VIII-2 SMP Negeri 1 Buay Pemuka Peliung. Kelas VIII-1 ditetapkan sebagai kelas eksperimen yang pembelajarannya menggunakan metode Drill, sedangkan kelas VIII-2 ditetapkan sebagai kelas kontrol yang pembelajarannya tanpa menggunakan metode Drill.

Pengumpulan data pada penelitian ini dilakukan menggunakan teknik tes. Tes yang digunakan pada penelitian ini adalah tes tulis (written test). Adapun bentuk tes tertulis yang dilaksanakan adalah multiple choice atau pilihan ganda. Tes disusun 25 nomor berbentuk pilihan ganda dengan 4 opsi jawaban yaitu a, b, c, dan d. Jika siswa menjawab benar mendapatkan skor 1 dan jika salah mendapatkan skor 0 . Uji instrumen yang dilakukan adalah uji validitas, uji reliabilitas, uji tingkat kesukaran soal, dan uji daya pembeda soal serta uji prasyarat analisis data yang meliputi uji normalitas dan uji homogenitas. Uji hipotesis dilakukan untuk mengetahui perbedaan antara kedua model yang digunakan. Pengujian hipotesis dilakukan menggunakan uji t. Uji t adalah salah satu uji statistika yang pengujian hipotesisnya didekati dengan distribusi normal. Berdasarkan penjelasan tersebut, maka analisis data pada penelitian ini digunakan uji $t$ polled varian atau sampel berpasangan. Alasan penggunaan uji $t$ polled varian adalah jumlah $n_{1} \neq n_{2}$, data pada penelitian ini berdistribusi normal, serta varian data $(\sigma 2)$ diketahui (Sugiyono, 2013:197). Pengujian hipotesis menggunakan uji $t$ polled varian dilakukan menggunakan rumus:

$$
t=\frac{\bar{X}_{1}-\bar{X}_{2}}{\sqrt{\frac{\left(n_{1}-1\right) S_{1}^{2}+\left(n_{2}-1\right) S_{2}^{2}}{n_{1}+n_{2}-2}\left(\frac{1}{n_{1}}+\frac{1}{n_{2}}\right)}}
$$

\section{HASIL DAN PEMBAHASAN}

\section{Hasil}

Meskipun hasil belajar kelas eksperimen dan kelas kontrol berada dalam kategori sama yaitu kategori sedang, namun dilihat dari jumlah peserta didik yang memperoleh nilai kategori tinggi dan rendah, hasil belajar kelas ekperimen yaitu kelas VIII-1 yang pembelajarannya menerapkan metode Drill lebih baik dibandingkan hasil belajar peserta didik kelas VIII-2 yang pembelajarannya menerapkan metode ceramah.

\section{Pembahasan}

Penelitian ini dilaksanakan di SMP Negeri 1 Buay Pemuka Peliung khususnya di kelas VIII. Penelitian dilaksanakan pada mata pelajaran Pendidikan Agama Islam materi pembelajaran Macammacam Sujud. Penelitian dilaksanakan di dua kelas yaitu kelas eksperimen dan kelas kontrol. Kegiatan penelitian dilakukan melalui pembelajaran di dua kelas yaitu kelas VIII-1 dan kelas VIII-2. Pembelajaran di kelas VIII-1 dilaksanakan menggunakan metode Drill dan diikuti oleh 25 orang peserta didik. Pembelajaran di kelas VIII-2 dilaksanakan menggunakan metode ceramah dan diikuti oleh 26 orang peserta didik. Pembelajaran dilaksanakan oleh peneliti yang memiliki peran ganda yaitu sebagai peneliti sekaligus sebagai guru. Pada akhir pembelajaran dilakukan tes untuk mengetahui hasil belajar peserta didik kedua kelas dan dianalisis dengan hasil sebagai berikut:

\section{Kelas Eksperimen}

Kelas eksperimen adalah kelas yang pembelajarannya menggunakan metode Drill yaitu kelas VIII-1 dengan jumlah peserta didik sebanyak 25 orang. Kegiatan pembelajaran dilaksanakan 
tiga kali pertemuan. Pada pertemuan pertama, kegiatan pembelajaran kurang dapat berjalan maksimal karena peserta didik belum memahami langkah-langkah pembelajaran menggunakan metode Drill. Pada pertemuan kedua dan ketiga, peserta didik telah memahami langkah-langkah pembelajaran sehingga pembelajaran dapat berjalan dengan maksimal. Pada pertemuan keempat dilakukan evaluasi untuk mengetahui hasil belajar peserta didik.

Berdasarkan analisis hasil tes diketahui bahwa dari 25 orang peserta didik terdapat 8 peserta didik atau $32 \%$ berada pada rangking atas atau memperoleh nilai kategori tinggi, 16 peserta didik atau $60 \%$ memperoleh nilai kategori sedang, dan hanya terdapat 1 peserta didik atau $4 \%$ memperoleh nilai kategori rendah dengan nilai rata-rata 78,40. Data tersebut menunjukkan bahwa hasil belajar peserta didik kelas eksperimen yang pembelajarannya menggunakan metode Drill adalah sedang. Data hasil tes pada kelas eksperimen menunjukkan bahwa metode Drill efektif diterapkan pada mata pelajaran Pendidikan Agama Islam. Melalui penerapan metode Drill peserta didik berupaya berperan aktif mengikuti seluruh kegiatan pembelajaran sehingga peserta didik lebih memahami materi pembelajaran. Setelah dilakukan pembelajaran dan evaluasi, dari 25 peserta didik hanya terdapat 1 orang peserta didik atau 4\% yang memperoleh nilai kategori rendah. Hal tersebut menunjukkan bahwa metode Drill efektif untuk diterapkan pada pembelajaran Pendidikan Agama Islam di kelas VIII SMP Negeri 1 Buay Pemuka Peliung.

\section{Kelas Kontrol}

Kelas kontrol adalah kelas yang pembelajarannya menggunakan metode ceramah yaitu kelas VIII-2 dengan jumlah peserta didik sebanyak 26 orang. Kegiatan pembelajaran dilaksanakan tiga kali pertemuan. Kegiatan pembelajaran dilakukan sesuai dengan langkah-langkah kegiatan pembelajaran yang telah digunakan di kelas VIII-2 yaitu menggunakan metode ceramah. Kegiatan pembelajaran dilakukan dengan memberikan catatan kepada seluruh peserta didik kemudian peneliti yang bertindak sebagai guru menjelaskan materi pembelajaran secara lisan. Setelah kegiatan pembelajaran berakhir, dilakukan tes untuk mengetahui hasil belajar peserta didik.

Berdasarkan analisis hasil tes diketahui bahwa dari 26 orang peserta didik terdapat 1 peserta didik atau 3,85\% yang memperoleh nilai kategori tinggi, 20 peserta didik atau $76,92 \%$ memperoleh nilai kategori sedang, sedangkan 5 peserta didik atau $19,23 \%$ memperoleh nilai kategori rendah dengan nilai rata-rata kelas sebesar 67,69. Data tersebut menunjukkan bahwa hasil belajar peserta didik kelas kontrol yang pembelajarannya menerapkan metode pembelajaran ceramah adalah sedang. Data hasil tes pada kelas kontrol menunjukkan bahwa metode pembelajaran ceramah kurang efektif diterapkan pada mata pelajaran Pendidikan Agama Islam. Penerapan metode ceramah memposisikan peserta didik sebagai objek belajar yang hanya mendengarkan penjelasan guru. Keadaan tersebut menjadikan aktivitas belajar peserta didik menjadi rendah. Bahkan, selama kegiatan pembelajaran terdapat peserta didik yang tidak mendengarkan penjelasan guru, berbicara atau mengobrol dengan teman sebangku dan tidur. Keadaan tersebut berimplikasi pada pencapaian hasil belajar peserta didik yang kurang maksimal dimana hanya terdapat 1 peserta didik atau 3,85\% yang memperoleh nilai kategori tinggi, sedangkan 5 peserta didik atau 19,23\% memperoleh nilai kategori rendah. Hal tersebut menunjukkan bahwa metode ceramah kurang efektif untuk diterapkan pada pembelajaran Pendidikan Agama Islam di kelas VIII SMP Negeri 1 Buay Pemuka Peliung.

\section{Pengaruh Metode Drill Terhadap Hasil Belajar Pendidikan Agama Islam Peserta Didik}

Setelah data masing-masing kelas diketahui dan dianalisis, langkah selanjutnya adalah melalukan analisis data untuk mengetahui ada atau tidak pengaruh metode Drill terhadap hasil belajar peserta didik. Analisis data dilakukan menggunakan uji $t$ polled varian. Berdasarkan hasil uji $t$ polled varian diperoleh harga $t_{\text {nitung }}$ sebesar $=4,27$. Jika dikonsultasikan dengan harga kritik $t$ pada taraf signifikansi 5\% atau interval kepercayaan 95\% dengan $\mathrm{db}=\left(\mathrm{N}_{1}+\mathrm{N}_{2}-2\right)=25+26-2$ $=49$ maka diperoleh $t_{\text {tabel }}=2,02$. Data tersebut menunjukkan bahwa $t_{\text {hitung }}>t_{\text {tabel }}$ atau 4,27 $>2,02$. Karena $t_{\text {hitung }} 4,27$ lebih besar dari harga $t_{\text {tabel }}=2,02$ pada taraf signifikan $5 \%$ maka $H_{\circ}$ yang menyatakan tidak terdapat pengaruh yang signifikan penerapan metode Drill terhadap hasil belajar 
mata pelajaran Pendidikan Agama Islam peserta didik kelas VIII SMP Negeri 1 Buay Pemuka Peliung ditolak, sedangkan $\mathrm{H}_{\mathrm{a}}$ yang menyatakan terdapat pengaruh yang signifikan penerapan metode Drill terhadap hasil belajar mata pelajaran Pendidikan Agama Islam peserta didik kelas VIII SMP Negeri 1 Buay Pemuka Peliung diterima.

Hasil uji hipotesis menunjukkan bahwa secara nyata terdapat terdapat pengaruh yang signifikan metode Drill terhadap hasil belajar mata pelajaran Pendidikan Agama Islam materi Macammacam Sujud peserta didik kelas VIII SMP Negeri 1 Buay Pemuka Peliung Tahun Pelajaran 2018/2019. Peserta didik yang pembelajarannya menerapkan metode Drill memiliki hasil belajar mata pelajaran Pendidikan Agama Islam lebih baik dibandingkan dengan peserta didik yang pembelajarannya menerapkan metode ceramah. Hal tersebut terbukti dari tabel persentase yang menunjukkan bahwa pada kelompok peserta didik yang pembelajarannya menerapkan metode Drill terdapat 8 peserta didik atau $32 \%$ berada pada rangking atas atau memperoleh nilai kategori tinggi, 16 peserta didik atau $60 \%$ memperoleh nilai kategori sedang, dan hanya terdapat 1 peserta didik atau $4 \%$ memperoleh nilai kategori rendah. Adapun pada kelas kontrol hanya terdapat 1 peserta didik atau $3,85 \%$ yang memperoleh nilai kategori tinggi, 20 peserta didik atau $76,92 \%$ memperoleh nilai kategori sedang, sedangkan 5 peserta didik atau 19,23\% memperoleh nilai kategori rendah.

\section{PENUTUP}

Berdasarkan analisis dan pembahasan hasil penelitian yang telah dilaksanakan dapat disimpulkan sebagai berikut:

1. Hasil belajar mata pelajaran Pendidikan Agama Islam peserta didik yang pembelajarannya menerapkan metode Drill di kelas VIII SMP Negeri 1 Buay Pemuka Peliung adalah tinggi yaitu dari 25 peserta didik terdapat 13 peserta didik atau $52 \%$ yang memperoleh nilai kategori tinggi dengan nilai rata-rata kelas sebesar 78,40.

2. Hasil belajar mata pelajaran Pendidikan Agama Islam peserta didik yang pembelajarannya menerapkan metode ceramah di kelas VIII SMP Negeri 1 Buay Pemuka Peliung adalah rendah yaitu dari 26 peserta didik terdapat 14 peserta didik atau $53,85 \%$ memperoleh nilai kategori rendah dengan nilai rata-rata kelas sebesar 67,69.

3. Berdasarkan hasil uji hipotesis diperoleh harga $t_{\text {hitung }} 4,27$, sedangkan harga $t_{\text {tabel }}$ adalah 2,02 sehingga harga $t_{\text {hitung }} 4,27$ tidak terletak antara $-t_{\text {tabel }} \leq t_{\text {hitung }} \leq t_{\text {tabel }}$ pada taraf signifikan $5 \%$ sehingga $H_{0}$ ditolak artinya terdapat pengaruh penerapan metode Drill terhadap hasil belajar mata pelajaran Pendidikan Agama Islam peserta didik kelas VIII SMP Negeri 1 Buay Pemuka Peliung.

Berdasarkan hasil penelitian yang menunjukkan terdapat pengaruh penerapan metode Drill terhadap hasil belajar mata pelajaran Pendidikan Agama Islam peserta didik kelas VIII SMP Negeri 1 Buay Pemuka Peliung, maka dapat disarankan sebagai berikut:

1. Guru dalam melaksanakan pembelajaran menggunakan metode Drill hendaknya memberikan berbagai pengarahan dan pemahaman kepada peserta didik terhadap langkah-langkah pembelajaran menggunakan metode Drill agar kegiatan pembelajaran dapat berjalan sesuai dengan rencana kegiatan pembelajaran yang telah disusun.

2. Peserta didik dalam mengikuti kegiatan pembelajaran hendaknya dapat senantiasa berperan aktif mengikuti seluruh kegiatan pembelajaran terutama dalam penerapan metode Drill.

3. Mengingat hasil belajar peserta didik yang pembelajarannya menggunakan metode ceramah kurang maksimal, hendaknya guru dapat menvariasikan metode ceramah dengan metode pembelajaran yang lebih mengedepankan aktivitas belajar siswa.

4. Berdasarkan hasil penelitian yang menunjukkan terdapat pengaruh metode Drill terhadap hasil belajar peserta didik, maka hendaknya guru dapat mengujicobakan penerapan metode Drill pada mata pelajaran lain atau pada materi pembelajaran lainnya sehingga dapat memperkuat atau 
menguji kebenaran hasil penelitian ini.

5. Guru hendaknya dapat menjadikan hasil penelitian ini sebagai bahan pertimbangan dalam menerapkan metode Drill pada kegiatan pembelajaran yang dilaksanakan.

\section{UCAPAN TERIMAKASIH}

Peneliti mengucapkan terima kasih kepada STKIP Nurul Huda Sukaraja Buay Madang OKU Timur, SMP Negeri 1 Buay Pemuka Peliung, LPPM STKIP Nurul Huda yang telah memberikan kontribusi lain dalam penelitian ini.

\section{DAFTAR PUSTAKA}

Budiningsih, Asri, C. 2011. Belajar dan Pembelajaran. Jakarta: Rineka Cipta.

Dantes, Nyoman. 2012. Metode Penelitian. Yogyakarta: Andi Offsed.

Djamarah, Syaiful Bahri. 2010. Strategi Belajar Mengajar. Jakarta: Rineka Cipta.

Hawi, Akmal. 2008. Pendidikan Agama Islam. Palembang: Excellen Publishing.

Roestiyah. 2008. Strategi Belajar Mengajar. Jakarta: Rineka Cipta.

Sanjaya, Wina. 2010. Strategi Pembelajaran Berorientasi Proses Pendidikan. Jakarta: Kencana.

Sudjana, Nana. 2012. Berbagai Metode Pembelajaran Aktif dan Kreatif. Jakarta: Bumi Aksara.

Sudjana, Nana. 2008. Evaluasi Hasil Belajar. Bandung: Remaja Rosdakarya.

Sugiyono. 2013. Dasar-dasar Statistik Pendidikan. Bandung: Alfabeta.

Sumiati dan Azra. 2008. Metode Pembelajaran. Bandung: CV. Wacana Prima.

Suparno. 2008. Mengembangkan Profesionalitas Guru. Jakarta: Depdiknas.

Tu'u, Tulus. 2007. Pengembangan Teknik-teknik Penilaian Belajar. Bandung: CV. Wacana Prima. 